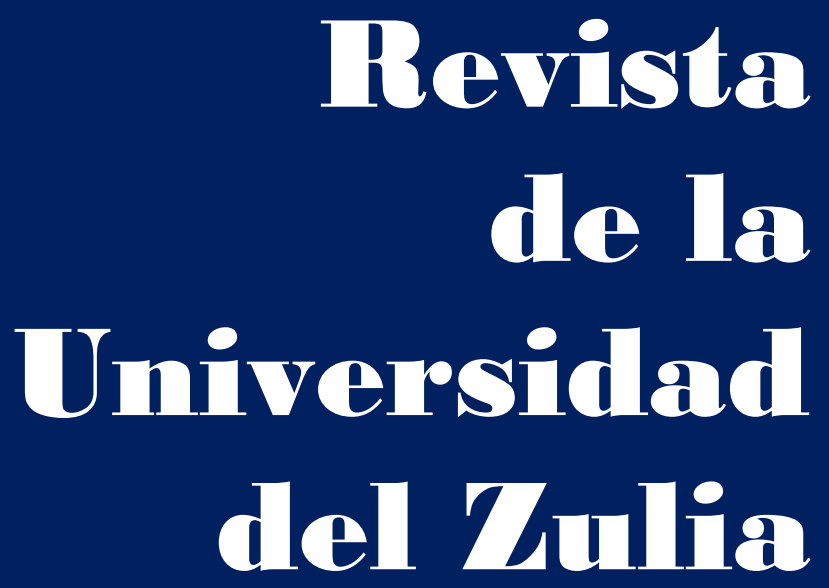

Fundada en 1947

por el Dr. Jesús Enrique Lossada

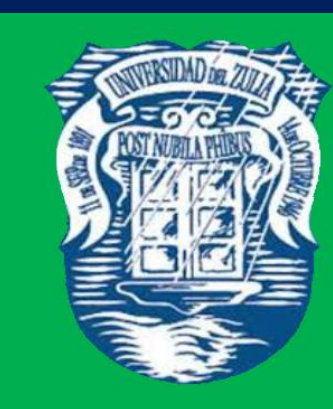

Ciencias del

Agrad,

Ingemiería

y Tecinología

\section{Aกัต 13 No $\mathbf{3 6}$} Enero - Abril 2022

Tercera Épaca

Maracailbo-Venezuela 


\title{
Robots in aerospace industry
}

Leonid B. Sobolev *

\begin{abstract}
Robotization is a logical continuation of computerization and automatization of industrial and service processes on previous stage of world-wide economy's evolution development. Before, automatic machines with computer numerical control and automatic lines have replaced workers with completing many typical production operations by doing it with more speed and accuracy. In development of automatization, industrial and service robots have additional sensors (analogues for human senses' organs), and they can choose the program of built-in computer, depending on operators' commands in regime of remote control or sensors' signals in autonomous regime. Robotization with computerization and automatization is a necessary part of fourth industrial revolution, in which world-wide economy is. Robots are already working everywhere: in industrial workshops, on farmlands, in hospitals and in replacing "labor" resource with "capital" resource, because such replacement has economic value. The goal of this article is analysis the use of robots in world-wide aerospace industry and robotization impact on the labor market.
\end{abstract}

KEY WORDS: robotics; industrial robots; service industries; aerospace industry; vehicles.

* Moscow Aviation Institute (National Research University), 125993 Volokolamskoe highway 4, Moscow, Russia. ORCID: https://orcid.org/0000-0003-3697-7799. E-mail: sobolev_mai@mail.ru 


\section{Robots en la industria aeroespacial}

RESUMEN

La robotización es una continuación lógica de la informatización y automatización de los procesos industriales y de servicios en la etapa anterior del desarrollo de la evolución de la economía mundial. Antes, las máquinas automáticas con control numérico por computadora y líneas automáticas han reemplazado a los trabajadores para completar muchas operaciones de producción típicas al hacerlo con más velocidad y precisión. En el desarrollo de la automatización, los robots industriales y de servicios tienen sensores adicionales (análogos para los órganos de los sentidos humanos), y ellos pueden elegir el programa de computadora incorporada, dependiendo de los comandos de los operadores en régimen de control remoto o señales de sensores en régimen autónomo. La robotización con informatización y automatización es la parte necesaria de la cuarta revolución industrial, en la que se encuentra la economía mundial. Los robots ya están funcionando en todas partes: en talleres industriales, en tierras de cultivo, en hospitales y en la sustitución de recursos "laborales" por recursos "de capital", porque dicha sustitución tiene valor económico. El objetivo de este artículo es analizar el uso de robots en la industria aeroespacial mundial y el impacto de la robotización en el mercado laboral.

PALABRAS CLAVE: robótica; robots industriales; industrias de servicio; industria aeroespacial; vehiculos.

\section{Introduction}

We should distinguish automatization and robotization. Robot, according to International Federation of Robotics (IFR) must be able to make three types of operations: Sense, Think and Act, i.e. has a sensitive element (or some sensitive elements), built-in computer with software and making mechanism, which comes as technical or intellectual device. Automatization answers only one or two of the mentioned conditions. Robots can have different sizes (from micro-devices for bio-medical research to giant robotic industrial systems), different view (from human-like to absolutely not-normal) and different skills depending on sensors' type and computers' software (Yang et al., 2018).

More and more countries (developed or developing) understand the meaning of robotization for developing their economies and use robots in different industrial spheres and service industry. Robotics became independent industry, including hundreds of big, middle and small enterprises. There appeared national robotic associations, which are coordinated by IFR, made in 1987 as non-commercial organization. IFT collects statistical 
REVISTA DE LA UNIVERSIDAD DEL ZULIA. 3a época. Año 13 N 36, 2022

Leonid B. Sobolev /// Robots in aerospace industry, 241-256 DOI: http://dx.doi.org/10.46925//rdluz.36.16

data about industrial markets and service robots in the world, accompanies completing international conferences and robotic symposiums.

IFR divides robots into industrial and service ones in connection with separating economy in two sectors: industry and service. Therefore, service robots are also divided in two segments. The first segment includes professional robots, taking part in labor activity (medicine, trade, logistics, guard, etc.) The second segment is everyday robots, which help completing home works and leisure (vacuum cleaners, lawn mowers, game robots, "smart home", etc.) One of the directions of professional service robots is projecting and production of military robots (scouts, sappers, orderlies), which are made for completing defined by armed forces functions.

For comparative analysis of robotic industry condition in countries and separate companies there are usually four quantitative indicators: revenue, number of established robots (in the country, industry or separate Company), robotic density (number of robots for 10000 workers) and relative growth of this or that indicator during a defined time section. Modern robotics can surely be determined as one of the high-tech spheres of industry. It is clear that with appearing new sensor elements, development of computer technics, appearing new materials and technologies, one robots get "old" and they are being replaced by new generation of robots (Küpper et al., 2019).

Until the end of XX century robots were rather expensive and labor in many developing countries was cheap. That is why robots had restricted usage even in developed countries, because it was possible to transfer harmful and non-requiring high qualification manufacturing in countries with cheap work force. However, in the world there are constant differently developed trends on decreasing robots' prices and increasing the cost of work force in developing countries. Industrial robots find more and more wide usage in different spheres of many countries (Tilley, 2017).

IFR data shows that world-wide sales of industrial robots in 2018 have made $\$ 16.5$ billion, taking into consideration peripheral equipment, software and costs for setting: about $\$ 44.6$ billion. In quantitative expression there has been sold 422000 robots. Density of robotization on average has reached 99 units on 10000 workers. Main consumers of industrial robots in 2018 were: automotive industry (more than 120000 units, 30\% of the market), electronic and electrotechnical industries (105 000 units, 25\% of the market) and 
REVISTA DE LA UNIVERSIDAD DEL ZULIA. 3a época. Año 13 N³6, 2022

Leonid B. Sobolev /// Robots in aerospace industry, 241-256

DOI: http://dx.doi.org/10.46925//rdluz.36.16

metalworking and engineering industries (43 000 units, 10\% of the market). Despite the whole number of established robots in the world is already higher than 2 million units, their amount in different spheres continues to grow fast (Shaw, 2019).

World Economy Forum (WEF) in its annual report "The Future of the Jobs-2018" estimated the share of world-wide production as 29\%, which has been partly robotic (World Economic Forum, 2018). As it was mentioned before, the growth of demand on robots is accompanied by lowering their cost and expanding usage spheres. China more than other countries buys industrial robots and, according to the data of Company IFI Claims, leads in the amount of received patents and given applications for robotics $35 \%$ of the whole amount), what is two times more than holding the second place Japan (Keisner et al., 2016).

In 2019 the growth of sales of industrial robots was slowed down because of structural re-building of world-wide automotive industry (main consumer of industrial robots) and certain saturation of the consumer electronics market. In 2020 there was a pandemic of COVID-19, which has caused the crisis of touristic industry, and, as a result the demand falls for civil aircrafts. Further development of aerospace industry in the nearest perspective, including industry's robotization will depend on rapidness of solving mentioned problems (Yahoo finance, 2020). However, already in 2021, the recovery growth of the entire global economy and industries affected by COVID-19 began. The purpose of this article is to analyze the use of robots in the global aerospace industry, which is characterized by low production volumes and the widespread use of manual labor of highly skilled workers.

\section{Methodology}

The article uses Qualitative Case Study Methodology, which is widely used in studies related to the complexity or uncertainty of predicting the outcome. Aerospace sphere has started robotization with delay, caused by rather small amounts of airplanes supplies, space devices and surface equipment for this sphere. According to Flight Global, in 2019, there were 67 aerospace companies in the world with revenues in excess of \$1 billion and another 25 companies with revenues from $\$ 0.5$ billion to $\$ 1$ billion, in which the use of robots can increase the company's efficiency. Manufacturing components and assembly and control processes are connected with big amount of hand operations, which are difficult for robotization. Nevertheless, aerospace corporations more and more invest in robotization for 
REVISTA DE LA UNIVERSIDAD DEL ZULIA. 3a época. Año 13 N³6, 2022

Leonid B. Sobolev /// Robots in aerospace industry, 241-256

DOI: http://dx.doi.org/10.46925//rdluz.36.16

increasing the production flexibility and increasing labor productivity. Robots are widely used in space exploration.

There are about 400 companies working on the world-wide market, producing industrial robotics. Many small companies make robots' accessories or software. Companiesintegrators collect form the ready accessories robots by consumer's demands. Such individual robots are more expensive for the consumer than ready robots. In robotic industry there are many startups, created with the government support, which have made prototype and look for the investor or a big Company for organizing mass production. The article shows examples (cases) of successful cooperation between the aerospace and robotics industries, providing an increase in labor productivity, safety and quality of production, assembly and research work.

\section{Results}

\subsection{Industrial robots in aerospace corporations}

In aerospace industry the first to use robots in production processes were leaders of aircraft industry: Boeing, Airbus, Lockheed Martin and Bombarlber, who have reached rather high volumes of production. All these companies have created robotic departments, which

closely interact with leading Japanese and European manufacturers of industrial robots and with small companies, available to complete specialized order. Nowadays, the leading places in production of industrial robots for different spheres of industry are taken by big Japanese companies (FANUC, Yaskawa, Kawasaki, Nachi, Denso, Mitsubishi, Epson) and some European companies (ABB, KUKA, Staubli, Universal Robots). Therefore, four companies (FANUC, ABB, KUKA и Yaskawa) hold more than 50\% of the market. With them mostly interact leaders of the aircraft industry interact (Technavio Blog, 2019).

Thus, Boeing has implemented on its plants some robots of big industrial robots' manufacturers: Fanuc and Kuka. Boeing is used Fanuc robots for drilling, riveting, coating, painting, welding of aluminum structures and polishing. Robots of Kuka are established on the fuselage assembly lines B777 in the city Everett, where sections of fuselage are collected using rivets (about 60000 units). Two manipulators of Kuka funcion synchronically: one establishes and rivets fasteners and another inside the fuselage performs the function of an anvil. Drilling holes in the fuselage is made by robot of another famous Company Electroimpact Inc, which drills holes and installs fasteners. Clients of Electroimpact Inc, 
REVISTA DE LA UNIVERSIDAD DEL ZULIA. 3a época. Año 13 N³6, 2022

Leonid B. Sobolev /// Robots in aerospace industry, 241-256

DOI: http://dx.doi.org/10.46925//rdluz.36.16

except Boeing, are Northrop Grumman, Bombardier and Embraer. Four-year experience of using robots for assembling fuselages B777 has shown that on this stage of robotization the Company cannot fully decline the usage of experienced mechanics (Johnsson \& Shukovsky, 2019). The automatic Kuka platform omniMove also works on the Boeing enterprise for transferring large details. The Company has created its robotic research department (Boeing Research \& Technology - BR\&T), which has even patented fully robotic fuselage assembly line. It is known that Lockheed Martin also uses robots for fuselage assembly F-35 and painting with using Fanuc, Kuka and Comau robots.

Airbus also partners with Kuka: in 2016 the Company has given Airbus platforms omniMove for transferring parts of fuselage, which because of the weight and sizes are hard for transferring by cranes. Platforms can gather in "contents", that is why they are easy to adapt for details of different length. Since 2015 Airbus implements collaborative robots (cobots), which are workers' helpers. Mainly they are small robots on the wheels, which can move inside the fuselage of the being-built airplane safely for people working there. As the experience of airplanes' assembly robotization shows, small robots can become more profitable for aviation than big manipulators with lower cost and bigger universality. In this theme on the enterprise Airbus in Hamburg two robots on moving chassis Luise and Renate successfully work on the assembly line of A320, their function is drilling holes in the fuselage compartments for its further assembly. Before drilling, holes parts of fuselage are combined and perfectly flattened by laser. Spanish concern MTorres (Airbus division) has developed its small robot FDH (Flexible Drilling Head), which is moving in the fuselage and makes drilling and riveting. Since 2016 Airbus partners with a small Japanese Company Joint Robotics Laboratory for developing anthropomorphic robots (Norrris, 2013)

Except from drilling and riveting robots are widely used for welding, shape milling, painting, coating and non-destructive testing. Welding in the whole hardness of creation aviation technics is 40-50\%. Wings of modern airplanes have a complex construction, including fuel tanks, hydraulics, flaps, ailerons, etc. For completing works inside the wing there are developed robots, which have a snake-like shape. In 2014-2018 years, Euponean Union (EU) has financed 17 robotic projects with a common name Horizon 2020, where each one is made for developing industrial and service robotics. Three of them are connected to aircraft industry (AEROARMS, AEROWORKS, COMANOID). 


\subsection{Service Robots and Unmanned Aerial Vehicles (UAV)}

All types of robots, which do not participate in manufacturing SA are service robots. The main demand in this segment have logistic robots, military robots, medical robots, robots for guard and control. In 2018, according to IFR report, sales' volume of professional service robots (without taking into consideration UAV) was $\$ 9.2$ billion. Sales' volume of home service robots, such as vacuum cleaners, lawn mowers and play robots is $\$ 3.7$ billion (the growth is $15 \%$ ). The main developers of service robots are American companies: iRobot, Intuitive Surgical (manufacturer of medicated robots da Vinci), Chinese Company DJI (amateur quadcopters) and Japanese Company Nachi-Fujikoshi. Production of separate types of robots is also made by manufacturers of industrial robots mentioned before: Kuka, Omron и Yaskawa.

In air transportation industry in the near future we can expect appearance of service robots for helping service personnel in the airplane and in airports:

- robots-stewards;

- robotic check-in desks and boarding passes;

- robot police, equipped with television cameras, scanning the faces of people at the airport to find wanted criminals;

- robotic logistics systems for receiving and transporting baggage;

- robots informants;

- robots for cleaning airport premises.

Separate class of service robots are suggested by UAV or drones, which market is separated in two segments: military and civil UAV. According to the prediction of International Data Corporation, the world-wide market of UAV in the near future will grow at a steady pace. In 2018 the UAV market's volume made up $\$ 12.3$ billions, in which $\$ 7.2$ billion were used for military UAV and other $\$ 5.1$ billion were used for civil one. Further annual growth is expected to be about $20 \%$, just because of civil segment. The biggest developers in military segment are American, British and Israel companies: Boeing, BAE Systems, General Atomics, Israel Aerospace Industries and Elbit Systems (Gertler, 2012).

Market of civil UAV has separated in two parts: commercial (professional) drones and home (consumers) drones. In commercial segment of UAV developers DJI Company dominates which was the first to successfully lower costs and suggest apparats by the price 
REVISTA DE LA UNIVERSIDAD DEL ZULIA. 3a época. Año 13 N³6, 2022

Leonid B. Sobolev /// Robots in aerospace industry, 241-256

DOI: http://dx.doi.org/10.46925//rdluz.36.16

lower than \$1 000 for individual usage. Commercial drones are used in police, cinematographic, agriculture and cartography. With multi-copters of Chinese manufacturers there are successfully compete drones of American Company iRobot and drones of French Company Parrot, which suggests consumers models (Canis, 2015).

There are a lot of ideas of using drones for different services, however, it is far away from industrial production. Low-cost commercial drones' payload, range and reliability still leave a lot to be desired. There are examples of successful decisions. Thus, drones-savers of American Company Zipline deliver blood and medicine to Ruande, but they do not raise more than 2 kilograms, Amazon Company demands using UAV for logistic goals.

\subsection{Service Robots for Space}

Separate consideration demand service robots, used in space. There are some competitive space markets, which satisfy common demands of defense and civilian character, scientific needs for knowledge of near-earth space and the Universe, and individual leisure needs for space communications, television, precise location determination, weather predictions and even exotic space tourism. Production sector includes developing and manufacturing launch vehicles, spacecraft (SC) of various sizes and purposes and ground infrastructure (cosmodromes, tracking and communication points with space objects, etc.). Service sector includes launch services, telecommunications services, data on the state of the earth's surface, etc. About usage of industrial robots in space manufacturing there is little information, but in some spheres of space activity service robots received wide usage.

World-wide space market in 2018 by data of American analytic Company Bryce Space and Technology made up $\$ 360$ billion. The main income (more than $80 \%$ from world-wide economic activity in space) was received from sales of commercial products and services. These space products and services include launch services, telecommunications, broadcasting, navigation and the Earth observation. Other 20\% were for counties' government programs, taking part in space activity. The main share of costs (about $\$ 50$ billion) had the USA.

Space industry is one of the most high-tech and high-cost industries of monetary and intellectual character. The main players on this market are the USA, EU, China, Russia, Japan, Canada, Israel and India, which have SC of their own production and means of launching into near-earth orbits and interplanetary trajectories (launch vehicles). Because of 
REVISTA DE LA UNIVERSIDAD DEL ZULIA. 3a época. Año 13 N³6, 2022

Leonid B. Sobolev /// Robots in aerospace industry, 241-256

DOI: http://dx.doi.org/10.46925//rdluz.36.16

the necessity in big investments, which are not always occupied, there is widely known international partnership in holding scientific researches and building big space objects. Nowadays there is one such piloted SC of module type on near-earth orbit, whose name is International Space Station (ISS).

In recent years there are significant changes on space markets. Due to the appearance of new players in the industry (firstly Company SpaceX) and tightening of competition there decreases the cost of space launches. Production of SC is moved to the side of increasing the amount of small satellites for receiving more data about the state of the Earth's surface and the purposes of telecommunications. Space industry is becoming more available and attractive for other industries, public organizations and ordinary citizens. Space products and services in connection with traditional systems of telecommunications and monitoring the Earth's surface provide increasing services' quality and these services' availability.

All piloted space activity in service sphere is connected to cosmonauts' life risks, which start with rocket's launching and finish only after successful landing. That is why robots' usage in space industry is not only useful from the point of decreasing costs, but also are necessary from the point of dangers of being in outer space without a special protective spacesuit due to hard cosmic radiation. The main tools of space products are focused on big studying of the Moon, the Mars and other planets of Solar Systems, and also the possibility of making works in outer space.

For solving these tasks there are many different robotic systems, which can be separated in three types:

1. Orbital robots-manipulators for carrying out various work in orbit, which in turn are divided into three types; large manipulators for assembling complex structures in orbit or planets: small multifunctional manipulators and flying manipulators (Free-Flyers);

2. Collaborative robots-helpers in piloted SC;

3. Non-planetary stationary and mobile robots (rovers) equipped with manipulators.

According to distance to the Earth (and related signal's delay, while exchanging information between robot and operator) and also from the character of made work, robots can have three level of autonomy (control mode):

1. Tele management regime (operator always can control robot's work); 
REVISTA DE LA UNIVERSIDAD DEL ZULIA. 3a época. Año 13 N³6, 2022

Leonid B. Sobolev /// Robots in aerospace industry, 241-256

DOI: http://dx.doi.org/10.46925//rdluz.36.16

2. Semi-automatic (supervision) regime, when operator makes commands for changing works' program only when robot asks for it;

3. Automatic regime, when operator does not have the possibility to control the robot and only receives information from him (usually while working in the far outer space).

Space robots are important due to their ability to complete works in space, which are hard for cosmonaut or connected with life risk. In fact, every flight to space from the Earth's orbit ends with robots' death, because returning on the Earth is more expensive than creating new robot. Robots' delivery in space is an expensive "pleasure" (delivery to low orbit "costs" about 10 thousand dollars per kilogram), however, cheaper than a person, what makes it attractive for many space programs. Let us consider some examples of successfully realized and only projected space robots, which will be related or to manipulators, or to rovers that have manipulators (Wilcox et al., 2006).

\subsubsection{Manipulators}

In the end of 80 s the USSR was the only country, which was able to create piloted module station "Mir" in near-earth orbit, which existed in orbit for 14 years. The USA was the first to understand technology of creating multi-usage space ships (Shuttle), which were used for researching outer space and for flying to the Moon. After the USSR's collapse, Russia, in cooperation with the USA and other countries, became a participant in the construction of ISS, built on a modular basis using Russian docking devices. However, while assembling ISS there were used American remotely controlled manipulators SRMS (Shuttle Remote Manipulator System), which were delivered in Shuttle cargo compartments. Then on ISS there was mounted remotely controlled manipulator (Space Station Remote Manipulator - SSRMS «Canadarm 2»), later to it there was added flexible manipulator «Dextre» (Special Purpose Dexterous Manipulator - SPDM), which has rather enlarged functional abilities of SSRMS. Both manipulators were developed and produced by Canadian Company MDA (MacDonald, Dettwiler and Associates).

Manipulator Restore-L, made by NASA order by Company Space Systems/Loral (SSL), is an example of "flying" manipulator for development of technologies for servicing satellites in near-earth orbit. The first stage of project is launching a robotized SC for refueling an active satellite Landsat 7. After Restore-L will make rendezvous, capture, 
REVISTA DE LA UNIVERSIDAD DEL ZULIA. 3a época. Año 13 N³6, 2022

Leonid B. Sobolev /// Robots in aerospace industry, 241-256

DOI: http://dx.doi.org/10.46925//rdluz.36.16

refueling and correction of the satellite's orbit, NASA will begin to test a number of other key technologies that are needed to explore the Mars. Technologies of Restore- $\mathrm{L}$ include a system of autonomous navigation with supporting onboard radio electronics and small programmed robotic manipulators launched from SC to refuel the satellite or modernization.

Harder program of satellites' management DARPA in geostationary orbit (RSGS) is built on the same principal and allows making the following works with the usage of multifunctional manipulations:

- checking and reduction from mechanical malfunctions such as failures in deploying solar panels and antennas;

- help in completing orbital maneuvers;

- setting of dockable modules, allowing to upgrade SC.

Though both programs are focused on SC management technologies demonstration in orbital flight, between them there is a difference in management. Rover Restore- $\mathrm{L}$ is oriented on tele management from the Earth, while RSGS will complete tasks in autonomous regime because of the connection delay due to the large distance to the flight control center.

Nowadays the exit to the orbit of large-scale constructions is not possible due to not enough carrying capacity of existing launch vehicles and large sizes of the required head fairings. To one of the projects of building large-scales constructions in near-earth orbits we can add the project «SpiderFab» of the Company Tethers Unlimited Inc.

\subsubsection{Cosmonaut's Robots-Helpers}

According to the place of holding additional works, collaborative robots usually function or in the ISS habitable compartment and are safe, while interacting with cosmonaut, or are situated and make works outside the ISS. In 2011 to the ISS there was delivered anthropomorphic robot Robonaut-2 (R2), developed by NASA and General Motors. Robot R2 is made mainly for making reconstructive works in depressurized compartments and outside the ISS and is capable of performing simple operations with a set of instruments. In 2014 there was made an attempt to make modernization in the ISS board by providing it with two additional grips ("legs"). The attempt was not successful due to wiring problems and the robot was returned on the Earth. Nowadays all problems on R2 are solved and there is a plan to return R2 in the ISS for holding further tests. 
REVISTA DE LA UNIVERSIDAD DEL ZULIA. 3a época. Año 13 N³6, 2022

Leonid B. Sobolev /// Robots in aerospace industry, 241-256

DOI: http://dx.doi.org/10.46925//rdluz.36.16

In 2019 in the ISS there was delivered Russian anthropomorphic robot FEDOR for holding tests in work sphere. Tests have shown that robot can complete a few simple operations and needs revision. After series of tests the robot was returned on the Earth.

In the Institute of Robotics and Mechatronics of the German Center for Aviation and Astronautics, the anthropomorphic robot Justin has been designed to work in space, the main advantage of which is the ability to perform complex operations using 2 interacting grips ("hands").

\subsubsection{Rovers}

Up to nowadays with the usage of rovers deep researches of the closest planets started: the Moon and the Mars. Rovers-moonwalkers can be controlled from the Earth in tele management regime. On the Moon up to now there worked three managed rovers: Soviet "Lunokhod-1" (1970-1971), "Lunokhod-2" (1973) and Chinese moonwalker "Yuytu" (20132014). In 2020-2021 private companies Ispace (Japan) and SpaceX (USA) are planning to send two rovers-moonwalkers to the Moon.

Rovers Mars walkers are usually controlled in semi-automatic regime. The first to try to do it was the USSR, but all three attempts (Mars-2, Mars-3 and Mars-6) ended unsuccessfully. In 2016, ESA, together with Roscosmos, sent the Schiaparelly lander to Mars, but this attempt ended in failure. From the end of 1990s there were 4 American rovers successfully worked: Sojourner, Spirit, Opportunity and Curiosity, on which there were set manipulators for samples of soil, devices for studying the surface and climatic conditions and devices for transmitting the information received to the Earth. The fifth rover InSight has strated on May 5, 2018 and will start examining inner planet's composition: its crust, mantle and core for information on the history of the formation of the planet. Rover is equipped with manipulator InSight IDA (Instrument Deployment Arm), which is able to drill a well of 5 meters deep and measure heat fluxes and physical properties of the Marsian soil. Nowadays there are rover Curiosity and stationary geological manipulator InSight on the planet.

Japanese rover Hayabusa-1 in 2005 made a successful landing and sampling of soil samples from the near-earth asteroid Itokawa, which were delivered on the Earth in 2010. In 2018 another Japanese lander Hayabusa-2 made landing on the asteroid's Rugu surface and using three movable mini-rovers, which have different tools made series of researches, 
REVISTA DE LA UNIVERSIDAD DEL ZULIA. 3a época. Año 13 N³6, 2022

Leonid B. Sobolev /// Robots in aerospace industry, 241-256

DOI: http://dx.doi.org/10.46925//rdluz.36.16

including surveying the surface, measuring the temperature and mineral composition of the surrounding rocks. All information was transferred on the Earth.

\section{Discussion}

In the biggest aircraft building companies of the world (Boeing, Airbus, Lockheed Martin, Dassault Aviation), which have military and civil segments, growth of the labor productivity is a result of as growth of aviation production sales, as complex of activities for increasing production effectiveness (including automatization and robotization) (Sobolev, 2020). However, robotization creates fears, in aviation industry too, that robots will leave people without work. How much are justified these fears? Is there growing unemployment in the countries, which are leaders in implementation of industrial robots?

For answering these questions let us take such parameter as robotization density (number of robots on 10000 workers). According to statistical IFR data for 2018 the worldwide leaders are Singapore, South Korea, Germany and Japan. In these countries the robotization density makes more than 300 units and robots halp to develop electrical industry, automotive industry and aerospace industry. Other countries with developed aerospace industry come into the top 20 of countries by robotization density: USA, Canada, Italy, France, China (135-247) with the middle number of 99 robots around the world. The exception makes Brazil, Russia and India, where robotization density is very low (less than 10 robots), there are weakly developed automotive and electrical industries. China is an absolute leader by the number of bought robots, trying to keep the "world workshop" position. The researches have shown that unemployment on this stage of robotization does not increase in the countries with high level of robotization and work places, which are replaced by robots are compensated with the appearance of new work places on growing robotic industry (Rodgers III \& Freeman, 2019).

The following positive effect from robotization received the name "reshoring", which means return productions to developed countries with good investment climate that were transferred before to developing countries. Reshoring has become in the USA, which was caused by low costs on energy resources and economical effectiveness from robots' usage. The main reasons of reshoring are: growth of salary in developing countries and lowering robots' prices. The advantage of reshoring also consists in the fact that return of production allows companies create new work places in domestic country, easer logistics and lower 
REVISTA DE LA UNIVERSIDAD DEL ZULIA. 3a época. Año 13 N³6, 2022

Leonid B. Sobolev /// Robots in aerospace industry, 241-256

DOI: http://dx.doi.org/10.46925//rdluz.36.16

logical costs. By doing this, manufacturers can reduce the time for performing the task and quickly adapt production for local consumers (Reshoring Initiative, 2017).

There can be mentioned other positive effects from robotization. For example, replacing the human by robots on dangerous for life and health work places, such as painting automobiles and airplanes, underground works, outer space, serving patients in a pandemic. Robots are already successfully used in Japan for working in elderly houses, solving the world-wide problem of the nation getting old.

Then who is losing from robotization? There lose countries with low labor productivity and unqualified workers in all countries, which can be easily replaced by robots with higher productivity. Cheap work force was an advantage during the times, when robots cost rather high and could not compete in price with cheap work force in the third world countries. However, scientifically technical progress has changed the existing way of things. Robots has become cheaper and work force, in contrast, has become more expensive. Taking in addition transport costs for transferring raw materials and ready production, robotic production in developed countries is becoming competitive to the cheapest labor, not demanding knowledge and professional skills.

Conclusion

The analysis made in the article is built on the world-wide aerospace industry condition in 2018 and optimistic forecasts for the future. Economic crisis, connected with COVID-19 can even "whip up" development and production of separate types of service robots. There is the necessity in medical robots of different type, observation and control robots, aeroport service robots. Undoubtedly, there will continue development of UAV.

Analysis of aerospace robotics has shown that it is developing in three directions: complex manipulations (including "flying") for completing different works in open space, robots-helpers to cosmonauts in piloted flights and rovers for boarding on near-by planets of Solar systems for their detailed examination. More success in creation space robots the USA, Japan, EU and Canada have.

Robotics already has impact on labor market and this impact will only continue to grow. Robots are getting cheaper and their usage becomes more economically useful than hiring unqualified workers. From robotization there win more developed countries and 
REVISTA DE LA UNIVERSIDAD DEL ZULIA. 3a época. Año 13 N³6, 2022

Leonid B. Sobolev /// Robots in aerospace industry, 241-256 DOI: http://dx.doi.org/10.46925//rdluz.36.16

China, which have high density of robotization, what allows them decrease costs and hold the production in their countries' boarders.

\section{References}

Canis, B. (2015). Unmanned Aircraft Systems (UAS): Commercial Outlook for a New Industry. Retrieved from https://fas.org/sgp/crs/misc/R44192.pdf

Gertler, J. (2012). U.S. Unmanned Aerial Systems. Retrieved from https://fas.org/sgp/crs/natsec/R42136.pdf

Johnsson, J. \& Shukovsky, P. (2019). Boeing ditched the robots on its 777 line. Like Tesla, it needed the human touch. Retrieved from https:/www.latimes.com/business/story/2019-11-14/boeingshumans-step-in-after-robots-fumble-777-jet-assembly

Keisner, A., Raffo, J. \& Wunsch-Vincent, S. (2016). Robotics: Breakthrough Technologies, Innovation, Intellectual Property. Foresight and STI Governance, 10(2), 7-27.

Küpper, D., Lorenz, M., Knizek, C., Kuhlmann, K., Maue, A., Lässig, R. \& Buchne, T. (2019). Advanced Robotics in the Factory of the Future. Boston: Boston Consulting Group (BCG).

Norrris, G. (2013). Airbus's Automated Future Features Robotics. Retrieved from http://aviationweek.com/awin/airbus-s-automated-future-features-robotics

Reshoring Initiative (2017). Reshoring Initiative 2017 Data Report: Reshoring plus FDI job announcements up 2,800\% since 2010. Retrieved from https://reshorenow.org/content/pdf/2017ReshoringInitiativeDataReport.pdf

Rodgers III, W. \& Freeman, R. (2019). How Robots Are Beginning to Affect Workers and Their Wages. Retrieved from https://cf.org/content/report/robots-beginning-affect-workers-wages/

Shaw, K. (2019). World Robotics Report: Global Sales of Robots Hit \$16.5B in 2018. Retrieved from https://www.roboticsbusinessreview.com/research/world-robotics-report-global-sales-ofrobots-hit-16-5b-in-2018/

Sobolev, L. (2020). Labour Productivity in Different Segments of Aircraft Industry. Research in World Economy, 11(3), 245-250.

Technavio Blog (2019). Top 21 Industrial Robotics Companies in the World 2019. Retrieved from https://blog.technavio.com/blog/top-21-companies-in-the-industrial-robotics-market

Tilley, J. (2017). Automation, robotics and the factory of the future. Retrieved from https://www.mckinsey.com/business-functions/operations/our-insights/automationrobotics-and-the-factory-of-the-future

Wilcox, B., Ambrose, R. \& Kumar, V. (2006). Space Robotics. WTEC Panel Report on International Assessment of Research and Development in Robotics, 1, 25. 
REVISTA DE LA UNIVERSIDAD DEL ZULIA. 3a época. Año 13 N 36, 2022

Leonid B. Sobolev /// Robots in aerospace industry, 241-256

DOI: http://dx.doi.org/10.46925//rdluz.36.16

World Economic Forum (2018). The Future of Jobs Report 2018. Retrieved from https://www.weforum.org/reports/the-future-of-jobs-report-2018

Yahoo finance (2020). COVID-19 Impact on the Global Industrial Robotics Market - Expected to Grow at a CAGR of 10.4\% during 2020-2025; Down by -3\% on the Pre-COVID-19. Retrieved from https://finance.yahoo.com/news/covid-19-impact-global-industrial-152400580.html

Yang, G., Bellingham, J., Dupont, P. E., Fischer, P., Floridi, L., Full, R., Jacobstein, N., Kumar, V., McNutt, M., Merrifield, R., Nelson, B. J., Scassellati, B., Taddeo, M., Taylor, R., Veloso, M., Wang, Z. L. \& Wood, R. (2018). The grand challenges of Science Robotics. Science robotics, 3(14), 1-14. 